\title{
Towards an Urban Narrative Layers Approach to Decipher the Language of City Films
}

\author{
François Penz \\ University of Cambridge
}

Follow this and additional works at: https://docs.lib.purdue.edu/clcweb

Dedicated to the dissemination of scholarly and professional information, Purdue University Press selects, develops, and distributes quality resources in several key subject areas for which its parent university is famous, including business, technology, health, veterinary medicine, and other selected disciplines in the humanities and sciences.

CLCWeb: Comparative Literature and Culture, the peer-reviewed, full-text, and open-access learned journal in the humanities and social sciences, publishes new scholarship following tenets of the discipline of comparative literature and the field of cultural studies designated as "comparative cultural studies." Publications in the journal are indexed in the Annual Bibliography of English Language and Literature (Chadwyck-Healey), the Arts and Humanities Citation Index (Thomson Reuters ISI), the Humanities Index (Wilson), Humanities International Complete (EBSCO), the International Bibliography of the Modern Language Association of America, and Scopus (Elsevier). The journal is affiliated with the Purdue University Press monograph series of Books in Comparative Cultural Studies. Contact: <clcweb@purdue.edu>

\section{Recommended Citation}

Penz, François. "Towards an Urban Narrative Layers Approach to Decipher the Language of City Films." CLCWeb: Comparative Literature and Culture 14.3 (2012): <https://doi.org/10.7771/1481-4374.2041>

This text has been double-blind peer reviewed by $2+1$ experts in the field.

The above text, published by Purdue University Press (CPurdue University, has been downloaded 1893 times as of 11/ $07 / 19$.

This document has been made available through Purdue e-Pubs, a service of the Purdue University Libraries. Please contact epubs@purdue.edu for additional information.

This is an Open Access journal. This means that it uses a funding model that does not charge readers or their institutions for access. Readers may freely read, download, copy, distribute, print, search, or link to the full texts of articles. This journal is covered under the CC BY-NC-ND license. 


\title{
PURDUE
}

UNIVERSITY PRESS <http://www.thepress.purdue.edu>

\section{CLCWeb: Comparative Literature and Culture \\ ISSN 1481-4374 <http://docs.lib.purdue.edu/clcweb> Purdue University Press @Purdue University}

CLCWeb: Comparative Literature and Culture, the peer-reviewed, full-text, and open-access learned journal in the humanities and social sciences, publishes new scholarship following tenets of the discipline of comparative literature and the field of cultural studies designated as "comparative cultural studies." In addition to the publication of articles, the journal publishes review articles of scholarly books and publishes research material in its Library Series. Publications in the journal are indexed in the Annual Bibliography of English Language and Literature (Chadwyck-Healey), the Arts and Humanities Citation Index (Thomson Reuters ISI), the Humanities Index (Wilson), Humanities International Complete (EBSCO), the International Bibliography of the Modern Language Association of America, and Scopus (Elsevier). The journal is affiliated with the Purdue University Press monograph series of Books in Comparative Cultural Studies. Contact: <clcweb@purdue.edu>

\section{Volume 14 Issue 3 (September 2012) Article 7 François Penz, \\ "Towards an Urban Narrative Layers Approach to Decipher the Language of City Films" <http://docs.lib.purdue.edu/clcweb/vol14/iss3/7>}

\author{
Contents of CLCWeb: Comparative Literature and Culture 14.3 (2012) \\ Thematic Issue New Work in Landscape and Its Narration \\ Ed. Sofie Verraest, Bart Keunen, and Katrien Bollen \\ $<$ http://docs.lib.purdue.edu/clcweb/vol14/iss3/>
}

\begin{abstract}
In his article "Towards an Urban Narrative Layers Approach to Decipher the Language of City Films" François Penz investigates how film narratives may provide us with the perceptual tools to grasp complex urban phenomena. He posits that, in order to elicit the mechanisms that make up the projected image of city films, new analytical tools need to be devised. Penz demonstrates that the cinematic image is composed of a succession of narrative layers and suggests that the eye of the unsuspecting film spectator encounters a succession of narrative layers recomposed seamlessly into a single movie image on the screen. Penz identifies four narrative layers: the story and history of the buildings, the narratives and points of view of the city planning process, the tales and personal stories embodied by the passers-by, and the narrative intentions of the film itself. Penz uses his own moviemaking experiments to test the narrative layers hypothesis concentrating on observational cinema.
\end{abstract}


François Penz,

"Towards an Urban Narrative Layers Approach to Decipher the Language of City Films"

CLCWeb: Comparative Literature and Culture 14.3 (2012): <http://docs.lib.purdue.edu/clcweb/vol14/iss3/7>

Thematic Issue New Work in Landscape and Its Narration. Ed. Sofie Verraest, Bart Keunen, and Katrien Bollen

\section{François PENZ}

\section{Towards an Urban Narrative Layers Approach to Decipher the Language of City Films}

In this article I put forward the idea that cinema and the moving image are particularly suitable for the study of city narratives and help to grasp complex urban phenomena. I propose a new approach to decipher urban codes by breaking down the cinematic image into a series of discrete narrative layers, including the spatial narrative (buildings), the city planning narrative, the people's narrative and the directorial narrative; as a whole, these layers constitute the language of city films. This approach allows for the synthesis of a wide range of otherwise dispersed systems by bringing together different strands, themes, scales, and histories, which constitute the discursive formation pertaining to the city "object." The narrative layers methodology is an interdisciplinary approach to the study of the urban cinematic; it involves cognitive aspects as well as elements of architecture, urbanism, narrative theory, and film theory. It can be considered as one of a multitude of narrative forms, which have been "emancipated from literature and from fiction," a legacy of French structuralism, as narrative has been recognized as a "semiotic phenomenon that transcends disciplines and media" (Herman, Jahn, Ryan 344).

This study also relies on film's remarkable potential to carry information - a characteristic that is crucial to the analysis of the data in all four layers, but tends to be taken for granted. The aforementioned potential features prominently in Landau's analysis of the opening of Psycho: "the camera surveys from a high vantage point a busy urban center, and gradually starts to descend ... on a particular building, then on a particular window, through which we observe the opening scene of the film: Adultery (in fact, we infer it is adultery, by Hitchcock's unique 'touch', not through the dialogue, but from the uncommon noon time for a lovers' rendezvous, indicated by the clock on the wall) ... In terms of informativeness, one can describe this shot as a very steep climb from the nullest level to a highly informative one" (Landau 760). From the very first sequence, our narrative appetite is whetted. What is more, within fifty seconds the audience knows the location, as "Phoenix, Arizona" glides across the screen. We also know the exact date: Friday December 11. As a result, within a very short time span, all four narrative layers are filled with information. And of course, the visual information is complemented by the audio track, in this case Bernard Herrmann's musical score, which is central to the directorial narrative layer. A somewhat similar technique is used in the opening sequence of Zazie dans le Métro: a camera mounted at the front of a train slices through the city in a series of jump cuts, creating a cinematic sectional archaeology going from the countryside to the heart of Paris.

However, I am aware of Marie-Laure Ryan's remark that the "term 'narrative' has enjoyed a popularity that has seriously diluted its meaning" (3). It is therefore necessary to qualify the context within which I am using the term "narrative layers." In an essay published in 1966, Roland Barthes proposed a structural analysis model and he defines narrative as follows: "There are countless forms of narrative in the world. First of all, there is a prodigious variety of genres, each of which branches out into a variety of media, as if all substances could be relied upon to accommodate man's stories. Among the vehicles of narrative are articulated language, whether oral or written, pictures, still or moving, gestures, and an ordered mixture of all those substances ... Are we to infer from such universality that narrative is insignificant? ... Indeed how are we to control such variety, how are we to justify our right to distinguish or recognize them ... without reference to a common model?" (237). Barthes's statement on "countless forms of narrative" signals the start of the "narrative turn" in the wake of the explosion of narrative interest, partly due to the dissemination of the structuralist theories developed in France in the 1960s. Vincent Hevern discovered in 2004 that the number of citations in which the terms "narrative" or "narration" occurred grew by an astonishing 2569 percent between 1960 and 2001. However, it was Barthes who paved the way to a search for a "common model," which I believe would be applicable to the study of urban cinematics. My hypothesis relies on construing the cinematic image as the merger between the language of space and the screen language. The resulting image is the encounter between two major narrative forms, which in turn constitutes the language of city films. 
Many scholars have expanded on the notion of narrative and space, for example Vaudoyer, who in 1852 coined the expression "architecture parlante" (see Molok 49) in connection with Claude-Nicolas Ledoux's architectural oeuvre. More recently, in Language of Space, Bryan Lawson puts forward that "We use the language of space, then, for many purposes. Through it we can express our individuality ... we can demonstrate our dominance or submission and our status in society" (2). In other words, by "speaking" the language of space we can control and exploit its power. Sophia Psarra argues that "Narrative enters architecture in many ways, from the conceptual 'messages' it is made to stand for to the illustration of a design through models, drawings and other representational forms" (2). This implies that, when it comes to narrative, buildings embody a dual function as "a narrative requires a narrator and a reader in the same way in which architecture requires an architect and a viewer" (2). For Bernard Tschumi, however, it is in the dynamics of architectural sequences that an "implied narrative is always there" as it "combines the presentation of an event ... with its progressive spatial interpretation" and because "the route is more important than any one place along it" (163).

Tschumi's evocation of spatial narratives associated with bodily movement builds on a long tradition, going back to Viollet-le-Duc's notion of a spatial mise-en-scène (254), Choisy's interpretation of the Acropolis from the point of view of a mobile spectator (413) and Le Corbusier's concept of the promenade architecturale (Vol. 1, 60). The route, the promenade, and the architectural sequence all fulfill Abbott's basic definition of narrative as "the representation of an event or a series of events" (12) and fall within Ryan "metaphorical narratives," defined as "scenarios about collective entities rather than individuals ... and dramatizations that attribute agency to abstract objects' a definition, which she suggests can be applied to 'music and architecture' ... In a narratively conceived architecture, the visitor's discovery tour is plotted as a meaningful succession of events. This occurs in Baroque churches, where the visitor's tour is supposed to re-enact the life of Christ" (13).

I adopt Ryan's metaphor and combine it with Abbott's basic characterization, to define spatial narratives as the representation or succession of events imbued with dramatic functions. "Drama," in this case, has to be interpreted as the mise-en-scène of architecture, or of a street, "staged" for the passers-by. And the succession of events is the unfolding of the urban landscape as we walk. Streets evoke human and dramatic qualities, as proposed by Honoré de Balzac with regard to the human quality and the physiognomy of Paris (see Ferragus), but they are composed of individual buildings. And every one of them has its own history and story, the accumulation of which make up the physiognomy of the area. Therefore, the analysis of a cinematic street sequence requires attention to both the street narrative and the buildings' stories. Also worth considering is the fact that narrative is invariably defined as two parts, the story and the discourse: "story is an event or sequence of events (the action), and narrative discourse is those events as represented" (Abbott 16). Seymour Chatman points out that "The theory ... is dualistic: story is the what that is depicted: discourse is the how" (295). In the narrative layers approach, I consider the "what" to be the spatial narrative, the city planning narrative, and the people's narrative - in other words, "what may be called the existents (characters and settings), the objects and persons performing, undergoing, or acting as a background for them" (Chatman 296). The "how," then, is what I refer to as the directorial narrative, the discourse (discours), that is, the expression, the means by which the content is communicated, the set of actual narrative "statements" (Chatman 296):

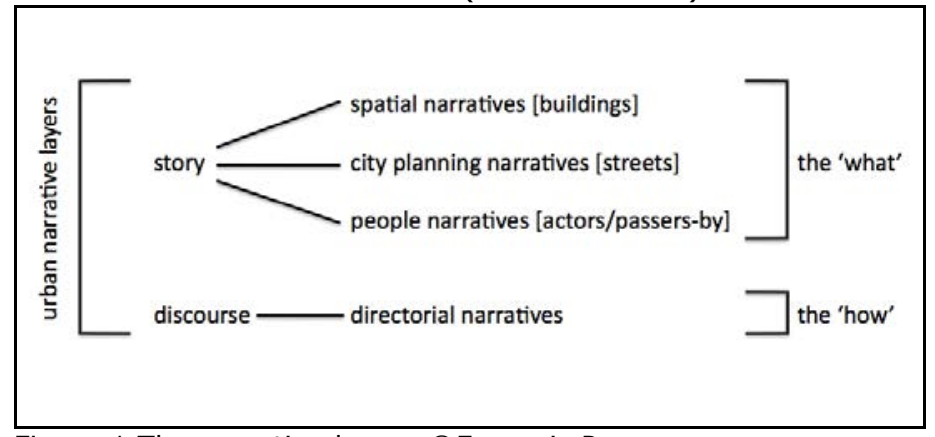

Figure 1 The narrative layers (CFrançois Penz 
The starting-point for my analysis of spatial narratives (Layer 1) is Do The Right Thing. In the film the brownstone house type is one of the main characters, as many scenes take place on the protruding stoops and the smooth brownstone fronts. Any critical analysis of the film is bound to include research on the history of and the narratives associated with the New York brownstone house. General spatial information is crucial to our basic comprehension of the world. In a classic Gestalt experiment (Gestalt Theory of Visual Perception <http://www.users.totalise.co.uk/ kbroom/Lectures/Gestalt.htm>), all of the objects and people in the classroom picture make sense. But if we remove the line that represents the floor, and arrange people and objects randomly, it becomes difficult to make sense of the everyday classroom scene. We are used to perceiving people and objects as they are organized in space, real or "reel" alike. Therefore, space is key to organizing narratives - a notion that I refer to as "spatially organized narratives" when it comes to films (see Penz, "Architecture" 159, "The Architectural" 43). In this respect, the village in Dogville is a poignant reminder of this Gestalt concept. The village is merely represented by walls and furniture placed on the stage, while the rest of the scenery, including additional walls, is painted on the stage with white lines. It is cinematic scenery at its most minimalist, on a par with the Gestalt classroom image mentioned above. Shot in a cinematic way while on a theatrical set, the scene makes perfect sense as the white lines serve to spatially orientate the spectator while, to a certain extent, the sound compensates for the lack of visual information.

Dogville relies partly on our prior knowledge of space to fill in the gaps, as it taps into our topdown perception whereby perceptual processes are "based on acquired knowledge and [narrative] schemas" (Branigan 37). Similarly, André Gardies interprets film narratives through a semionarratological approach (a mixture of semiotics and narratives), arguing that spaces create "expectations horizons" in the spectator (76). In other words, in our imagination, a space may call for certain actions; it is not neutral. Gardies uses the example of a saloon door opening in a Western, which creates an expectation on the part of the spectator that certain types of events may take place. However, this model becomes problematic when we are confronted with a new type of space, for which we do not yet have referential values and expectations. A case in point is the new Rolex building in Lausanne, designed by Sanaa Architects, for which Wim Wenders was asked to make a film: the result was If Buildings Could Talk, a 3D movie exhibited at the Venice Biennale in 2010. In the process, Wenders found himself confronted with a new type of space with which he had no prior experience, so that he did not have the "vocabulary" to describe it. Therefore, he resorted to observing the building and its users and in the process wrote a voice-over of the building "talking." In Layer 2, which pertains to streets and urban narratives, many of the spatial narrative mechanisms apply. For example, in the opening scene of Psycho, the words "Phoenix, Arizona" on the screen create certain expectations in the spectator and conjures up images and associations, which we bring to the film at its very start. The opposite is also true. In the opening shot of American Beauty, in which the camera glides over a typical US-American suburb, it would have been counterproductive for the director to indicate the exact location of the scene, as the setting is meant to synecdochically represent the generic US-American suburbs. But this might be the exception that confirms the rule, as the history of a street, how it came about, and its urban and planning context might be key to a movie and its place in history. For example, in the opening sequence of West Side Story, the camera glides over the urban grid of New York's West Side tenements, which were about to be demolished to make way for the Lincoln Center. And while urban redevelopment is not the subject of the film, the history and stories behind the planning struggle are represented in the film - a particularly poignant fact, given that the West Side narratives have only been preserved in celluloid form. Films can also reveal social practices where social relations are spatially organized, as is the case in La Haine. The spatially organized social relations, the practice of everyday life in the French suburbs, are there to be "read" and "extracted" from the film. The planning issues of the time are also embedded in the movie, not only in the form of a visual reminder of post-modernist social housing architecture or a documentation of the urban furniture and 1970s murals, but also, and more vividly, in the narratives. Indeed, the planning errors of the 1970s are the "dramatic engine" of La Haine: Chanteloup-les-Vignes, a cité on the west side of Paris, is connected to the Paris intra muros through a suburban rail line connection. As a result, Vinz, Said, and Hubert are stuck in Paris, unable to go back home, frustrated and bored, 
which has devastating consequences. By comparison, the "Bofill rich" town of Cergy-Pontoise, north of Chanteloup-les-Vignes, has been linked to Paris right from the start. Consequently, in Eric Rohmer's My Girlfriend's Boyfriend we follow a much more gentle narrative in the more up-market town of Cergy-Pontoise, where the protagonists allow themselves to dash to Paris for a soirée. In both films, the respective narratives dovetail with the urban histories and tactics, and they constitute textbook examples of well-matched spatially organized narratives. In La Haine, the complexity of the suburban reality is more vividly revealed than is the case in most sociological studies. Urban narratives come to the fore, and planning errors are presented in plain narrative language for all to comprehend. Even though the cité of Chanteloup-les-Vignes may have gained a few moments of glory beyond its expected "fifteen minutes of fame," it has not become a tourist attraction, unlike Montmartre in the wake of Amélie. The long-term legacy of La Haine is inextricably intertwined with its ability to heighten an audience's consciousness regarding suburban issues to a level that everyone can understand and discuss, which illustrates Jonathan Raban's statement that "The city as we imagine it, then, soft city of illusion, myth, aspiration, and nightmare, is as real, maybe more real, than the hard city one can locate on maps in statistics, in monographs on urban sociology and demography and architecture" (2).

Layer 3, the third component of the language of space, comprises the "city practitioners": the passers-by. Regarding the narrative function of pedestrians, Michel de Certeau states that "The act of walking is to the urban system what the speech act is to language" and that it has an "enunciative" function: it is a process of "appropriation of the topographical system on the part of the pedestrian" (97). This form of spatial appropriation is partially captured in Jean-Luc Godard's dialogue with a little girl about her going back and forth to school: "Godard: when you go to school, does the path belong to you or to the city? Little girl: ... it belongs to the city Godard: but when you walk on it, is it not a little yours? Little girl: it belongs to all those who walks on it" ("Godard: le chemin que tu fais pour aller à l'école c'est un chemin à toi ou c'est un chemin qui appartiens à la ville? Little girl: ... un chemin qui appartiens à la ville Godard: quant tu le parcours il est un peu à toi? Little girl: il est à tous ceux qui marche dessus" (unless indicated otherwise, all translations are mine). However, while pedestrians (individually and collectively) practice a form of spatial rhetoric, they all carry their own stories and enact their own narratives. In The Naked City, this is signaled by the memorable voice-over in the opening shot over Manhattan: "as you see we are flying over an island, a city a particular city, and this is the story of a number of people ... of New York itself and along with them a great many thousands of New Yorkers played out their roles." The voice-over concludes that "There are 8 million stories in The Naked City, this has been one of them." In other words, in a city, there are as many stories as there are people, and, to a certain extent, when a camera is used on a street, it unwittingly captures a "phrase" or a "paragraph" of people's spatial rhetoric, inscribed in their personal stories.

It is difficult to evoke people or the body in isolation, and the relationship between space and the body, which is central to cinema, has to be established. Henri Lefebvre has commented that "Every space is already in place before the appearance in it of actors ... The pre-existence of space conditions the subject's presence, action and discourse, his competence and performance" (57): prior to the arrival of an actor, a space is pregnant with expectation. For instance, in Le Samouraï, when Jeff Costello (Alain Delon), leaves Paris and passes behind the Porte d'Ivry metro map, he re-emerges in a suburban train station where he descends the stairs towards the station underpass; for a couple of seconds, the space is left empty: it has become a space of desolation. In the next shot, the camera is trained on the grey wall at the end of the underpass, awaiting Costello. A second later, the latter appears, so that the space turns into a place: it has been given its meaning, a sense of scale, and a purpose. The micro-moments during which spaces are not yet places are important, because they result in cinema that leaves space to space, and, in doing so, makes the appearance/disappearance of the body all the more significant. Similarly, Helsinki Forever examines whether the presence of stars glorifies what might otherwise be an anonymous space. To a certain extent, the film confirms Patrick Keiller's point that "the representation of urban spaces in films does seem to be a factor in the current scenarios of urban regeneration ... the sight of a familiar space in film can momentarily banish the sense of marginality that haunts even the most central urban locations" (382). It is not just the presence of a space in a film that can "momentarily banish" its "sense of marginality," as this phenomenon can only be achieved through the space's association with actors and "stars." For 
instance, no amount of documentaries and publications could have achieved more for New Zealand than The Lord of the Rings.

Much research has already been done on Layer 4, which is related to the directorial narratives in films. Of utmost importance in this context is Branigan's stance that "narrative is a perceptual activity that organizes data into a special pattern ... a way of organizing spatial and temporal data into a cause-effect chain of events" (3). Along similar yet complementary lines, Torben Grodal argues that "Narrative structure specifies some basic relations between perceptions, emotions, and acts, and connects to fundamental ways in which we experience the world" (10). This essentially cognitive and phenomenological approach is useful here as a way of tying up the language of space, part of the real world, mediated by the narratives of the film medium. The transformation of the spatial attributes into elements on screen is in the hands of the filmmaker, as we can assume that the space is a given in location filming. What I define here as the "directorial narrative" is paramount to our understanding of space. The Girl Chewing Gum is a case in point. The film consists almost entirely of a single continuous shot of Stamford Road in Dalston Junction, an area of East London. The camera is mostly trained on the offices of a plate-glass company at the corner of the street, and records passers-by as they go about their business. However, there is a voice-over as well, which transforms the real space into a screen space by "directing" the passers-by: "now I want the old man with white hair and glasses to cross the road ... come on quickly ... etc." The voice appears to direct reality, while, in fact, the commentary was added to the shot at a later stage. In an interview, John Smith explains that his approach at the time was as follows: "I'm going to film on a street corner, and I'll use a 400 foot roll of film, and I'll film what happens on the street, and then I'll direct it later" (Frye). This approach turns the ordinary space and passers-by into the city and actors by means of a simple directorial artifice.

It is the prerogative of the filmmaker and the cinematographer to frame and, in doing so, to choose what to exclude. The director, in this case, is a mediator, who shows viewers a world that s/he has chosen. This is illustrated by, for instance, the périphérique (the ring road around Paris) construction scene at the start of Godard's Two or Three Things I Know About Her. This is a seemingly simple scene: the camera is static, standing on the ring road, which arches to the left. The effect resonates with Rudolf Arnheim's description in Film as Art: "the effect of film is neither absolutely twodimensional nor absolutely three-dimensional, but something between. Film pictures are at once plane and solid" (12). Raoul Coutard's cinematography has a unique painterly quality; it plays with shapes and shadows, solid and void. Our senses struggle to keep the balance between 2D and 3D. Only the occasional movement of the workers below brings us back to a 3D world. In addition, it is highly unlikely for anyone to have seen this part of the périphérique construction in this way, which clearly illustrates Benjamin's argument that "Architecture has always represented the prototype of a work of art the reception of which is consummated by a collectivity in a state of distraction" (239). Therefore, the first thing Godard does is frame the world, and then, he gives it a duration, as, after nine seconds, the film cuts to a new scene. The directorial narrative implies the framing, timing, and transition most of what cinema is all about. In this case, a static observation is remediated by Godard for the viewer. The result is very different from, for instance, a still photograph of the same image, which once could consider for one second or an hour. In a photograph, the viewer chooses when to move on, but with Godard's scene, it is the director who decides how long the audience contemplates a certain scene before the film moves on to another set-up. Therefore, during a few seconds or even minutes, we are in effect experiencing "real time," which would be impossible with a photograph. Although Godard's scene seems simple enough, it features many narratives. For instance, it contains a "slice of history" of the Paris périphérique construction and how it relates to its surrounding, it evokes the political landscape with Godard's voice-over - "on August 19 an act was published concerning the governmental organization of the Paris region" - and, finally, there is the freestanding wheelbarrow that appears to be waiting to be picked up and therefore creates as sense of expectation. The scene operates on many different levels, ranging from the very basic (the wheelbarrow) to government affairs, but also everything in between.

Throughout the twentieth century, the avant-garde observed the city in new and innovative ways, in particular in the 1920s, with the advent of the city symphonies genre. However, by and large, 
fictional cinema has rarely ever taken the city as its subject. A noteworthy exception is Smoke, a film that provides a unique entry-point into the observation of the city through a work of fiction. Of interest here is Auggie, the character played by Harvey Keitel whose hobby is to make photographic recordings of his street corner, every morning at eight o'clock. Particularly relevant is the dialogue between Auggie and Paul, who is flipping through the pages of his photo albums. Auggie explains: "More than four thousand pictures of the same place. The corner of Third Street and Seventh Avenue at eight o'clock in the morning. Four thousand straight days in all kinds of weather. That's why I can never take a vacation. I've got to be in my spot every morning. Every morning in the same spot at the same time." Paul does not understand it, and therefore, Auggie continues, "It's my corner, after all. It's just one little part of the world, but things happen there, too, just like everywhere else. It's a record of my little spot." As Paul hurries through the pile of albums, Auggie remarks, "You'll never get it if you don't slow down, my friend ... You're hardly even looking at the pictures," to which a baffled Paul replies, "But they're all the same..." a comment that triggers Auggie to explain further: "They're all the same, but each one is different from every other one. You've got your bright mornings and your dark mornings. You've got your summer light and your autumn light. You've got your weekdays and your weekends. You've got your people in overcoats and galoshes, and you've got your people in T-shirts and shorts. Sometimes the same people, sometimes different ones. And sometimes the different ones become the same, and the same ones disappear. The earth revolves around the sun, and every day the light from the sun hits the earth at a different angle." In Smoke, Auggie emphasizes the passing of time and seasons through the people and their associated narratives, while the buildings (including his corner shop) set the stage for the lives of the unsung heroes of the everyday. To borrow de Certeau's words, "They are the walkers, Wandersmänner, whose bodies follow the thicks and thins of an urban 'text' ... these practitioners make use of spaces that cannot be seen ... paths that correspond in this intertwining, unrecognized poems" constituting a network of "intersecting writing ... that has neither author nor spectator" (93). However, by recording and observing the passers-by and their daily movements, Auggie is their spectator. He celebrates their achievements by hailing the everydayness of life in the city.

By means of a different medium, that of writing, Georges Perec's Species of Spaces and Other Pieces advocates a series of practical exercises, including the observation of the city by taking notes at a café terrace: "Observe the street, from time to time, with some concern for system perhaps. Apply yourself. Take your time ... Nothing strikes you. You don't know how to see. You must set about it more slowly, almost stupidly ... The buildings: note that they're on the comfortable, well-heeled side. Distinguish residential from official buildings ... Don't say, don't write, 'etc.' Make an effort to exhaust the subject ... You still haven't looked at anything, you've merely picked out what you've long ago picked out" (50). Perec also suggests a process of defamiliarization towards the observation of the city: "Until the scene becomes improbable, until you have the impression, for the briefest of moments, that you are in a strange town or, better still, until you can no longer understand what is happening or is not happening, until the whole place becomes strange, and you no longer even know that this is what is called a town, a street, buildings, pavements" (53). Importantly, both Auggie and Perec urge to "slow down," but only Perec urges us to fight the everyday and the familiar in order to notice the world around us.

One way to achieve the latter goal is to study the city through the observational camera, but not simply by relying on direct observation - real time, so to speak - but by "observing the observed," scrutinizing the result. William $\mathrm{H}$. Whyte, who spent sixteen years studying the small urban spaces of New York City through filming, commented on his method as follows: "We used photography a lot: $35 \mathrm{~mm}$ for stills, Super 8 for time-lapse, and $16 \mathrm{~mm}$ for documentary work. With the use of a telephoto lens, one can easily remain unnoticed, but we found that the perspective was unsatisfactory for most street interchanges. We moved in progressively closer until we were five to eight feet from our subjects. With a spirit level atop the camera and a wide-angled lens, we could film away with our backs half turned and thus remain unnoticed - most of the time" (4). The fact that Whyte filmed with his back half turned implies that the observation of what took place was analyzed at a later stage - an approach that is central to Whyte's work. I experienced the benefit of post-observation when filming in Les Halles in Paris (see Figure 2 left). The location was a crowded spot, filled with activities and noise, 
and although I was standing behind the camera, I did not notice an incident in front of me: one of the escalators suddenly stopped working, and people nearly fell on top of each other (see Figure 2 right). This was not a major event, but nevertheless significant enough to alter the flow of the "urban text" referred to by de Certeau. This became apparent to me only at a later stage, when I studied the tape.

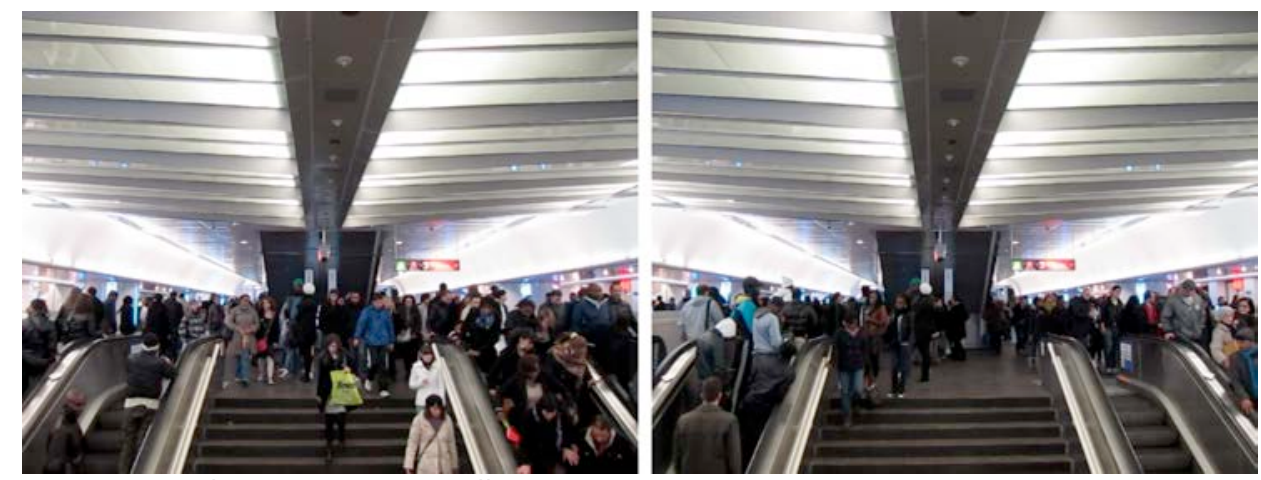

Figure 2 Escalator scene, Les Halles, Paris @François Penz

The work of Perec and Whyte, as well as the film Smoke were central to an observational workshop organized in Tallinn in July 2010. The occasion was the CinemArchitecture event (<http://expressivespace.org/research-CinemA.html>), part of a program initiated by Luis Urbano from the University of Porto, together with the universities of Cambridge and Liverpool, as well as the Estonian Academy of the Arts, and supported by the European Union's Erasmus program. This program ran over three years, touring Porto in 2008, Liverpool in 2009, and Tallinn in 2010. Some of the results were summarized by Maureen Thomas. Each school of architecture was represented by ten students and locations in Tallinn were the focus of the workshop with four practical exercises: "Observing a Species of Space," "Edit-in-the-Camera," "City Sinfonietta," and "Expressive Space." The instructions for "Observing a Species of Space" were based on Perec's practical exercises mentioned above. In groups of six, the students had to identify and observe a corner of the city. They were asked to "apply themselves and slow down," to note, sketch, or photograph (stills) what was around them. This was followed by the filming phase: setting up the camera on the tripod and shooting a twominute sequence. Going back to basics, they were "observing the observed," taking notes, and discussing. The main purpose of the exercise was to acquire the conceptual skills in order to help us grasp the observational camera's potential as a way to understand the city.

Next, I analyze one of the six exercises produced by applying the narrative layers framework. Figure 3 is a frame taken from a two-minute burst of a static camera. The scene takes place in the northern part of Tallinn and shows a summer sight by the sea. There are two children in the foreground, a boy and a girl, and a man is sunbathing in the background. The scene does not posit any relations or interaction between the man and the children. 


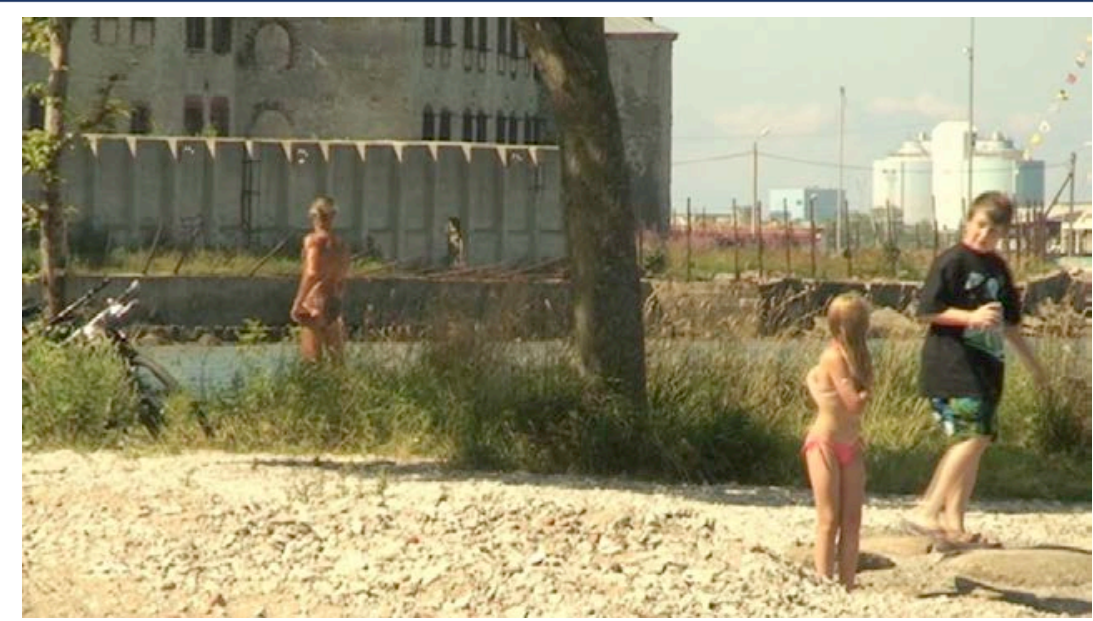

Figure 3 Tallinn observation filming (CFrançois Penz

The plan reveals that all elements on the screen were crushed onto it due to the foreshortening effect of the camera. The camera is placed at a distance from the scene and the zoom effect compacts the depth of field, so that the distances between the people and the buildings seem much smaller than they actually are. In this example, the observational camera takes us back to early cinema. The edges of the frame are played with; the two children, in particular, come in and out of frame. Some of the action takes us back to L'Arroseur arrosé by the Lumière Brothers (1895): it oscillates between slapstick, surrealist cinema, and voyeurism, all within the confines of a single two-minute burst of static filming. In an audience, the scene invariably triggers comments about the "people narratives," in particular when it comes to the character in the background and the two children, suggesting that people perceive or imagine a tension, while the scene itself does not signal any interaction between the characters. In fact, they are ignoring each other as well as the camera. What is more, as noted above, there is quite a gap between them. This is a product of what Branigan, using a cognitive approach, refers to as a top-down perception whereby perceptual processes are influenced by acquired knowledge. It is probable that, based on our knowledge, preconception, social conventions, and cultural expectations, we sense that background and foreground form an uneasy juxtaposition. Is the man in the background a nudist, or perhaps a voyeur? Where are the children's parents? The parents may just be a few meters away, off screen, but the scene provides no definite answers. The directorial narrative has dictated the framing and therefore the exclusion of potentially crucial information.

The fact that it is a summer scene, that there is water and people in swimming costumes, creates expectation horizons (after Gardies, see above) that pertain to what we associate with beach holidays: heat, sun, kids playing in water, and sailing boats. And yet, there is something uncanny about the scene that transcends the relationship between foreground and background characters. This may be due to the rather eerie setting: a liminal condition, semi-beach, semi-urban, part industrial setting. It is a hybrid place where we are not quite sure whether we are in the city or at the beach. This setting may explain our mixed expectation horizons. In that sense, the scene is a very good example of how a space influences our reading of a scene, and of how the visual identity of a city setting may affect the urban narrative. Figure 4 suggests that the eeriness of the scene is only due to the setting, including the formidable presence of the Patarei building, which functioned as a prison until 1991. 


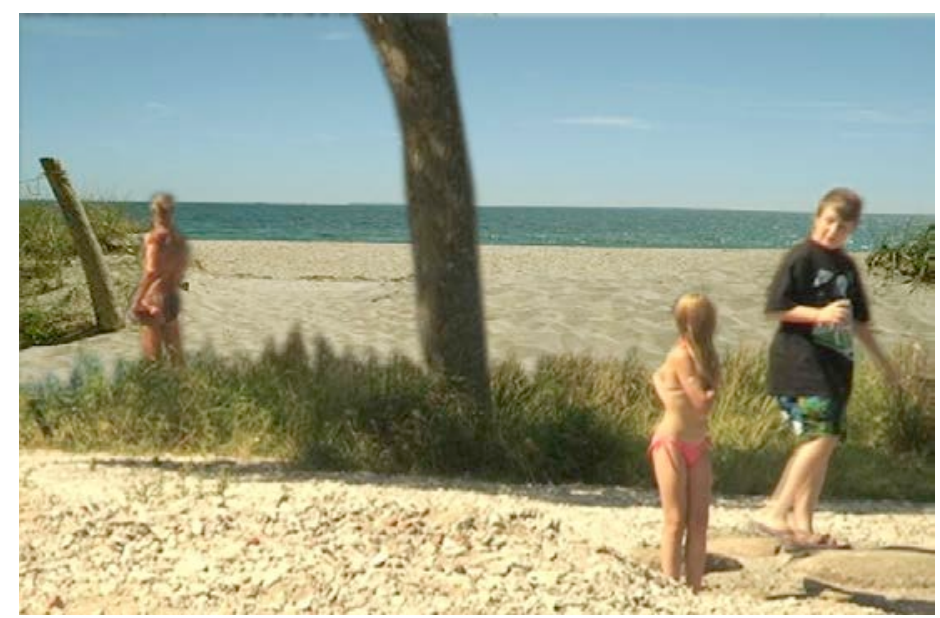

Figure 4 Digitally retouched frame (CFrançois Penz

By digitally replacing it, together with the Tallinn water disposal plant on the far right (see Figure 4), with a traditional sandy beach, every sense of ambiguity seems to be removed. The observational exercise demonstrates the transition from an unconsciously recorded - or naïve - space to a consciously recorded space, which becomes an expressive space. We can paraphrase Keiller and turn his aforementioned remark on the relationship between urban spaces and films on its head: "the sight of an unfamiliar space in a liminal location in film can momentarily accentuate the sense of marginality of an everyday scene" (381). Clearly, the scene under consideration illustrates how a recording of everydayness may be dramatized because of the setting rather than the people in it. Finally, Figure 5 below elicits, in the manner of an exploded axonometric, the different narrative layers by exposing them as individual entities.

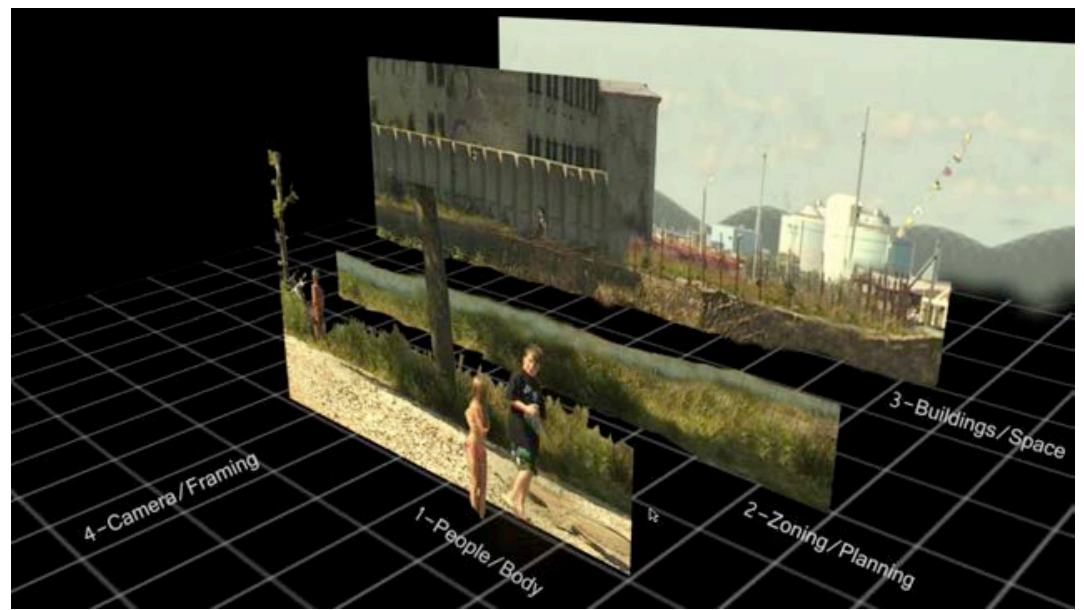

Figure 5 The urban narrative layers (CFrançois Penz (image manipulation: Amir Soltani)

In conclusion, I demonstrate that the narrative layers approach is a potentially useful tool to unlock the language of city films. In particular, it shows that the cinematic image synthesizes a wide range of otherwise discursive systems. It is most promising as an approach to observational cinema, as it makes it easier to excavate and exploit the richness of the data culled along the way. The narrative layers approach allows for an in-depth analysis of each layer in turn - a necessary exercise in order to break down the urban code. City films provide us with a wealth of information, but we have to go beyond the action and the fiction in order to appreciate their documentary qualities. The narrative layers methodology allows for the streets and the urban fabric to come to the fore, and for their impact to be measured and weighed accordingly. It is only then that the stories contained in the "what" (represented in Figure 1) can be disentangled from the "how" of the directorial narrative. 


\section{Works Cited}

Abbott H. Porter. The Cambridge Introduction to Narrative. Cambridge: Cambridge UP, 2008.

American Beauty. Dir. Sam Mendes. Hollywood: DreamWorks Pictures, 1999.

Arnheim, Rudolf. Film as Art. Berkeley: U of California P, 1957.

Balzac, Honoré de. Ferragus: Chief of the Devorants. 1833. Trans. Katharine Prescott Wormeley. Gloucestershire: Dodo P, 2006.

Barthes, Roland. "An Introduction to the Structural Analysis of Narrative." Trans. Lionel Duisit. New Literary History 6.2 (1975): 237-72.

Branigan, Edward. Narrative Comprehension and Film. 1992. London: Routledge, 1997.

Benjamin, Walter. "The Work of Art in the Age of Mechanical Reproduction." Illuminations. Ed. Hannah Arendt. Trans. Harry Zohn. London: Pimlico, 1999. 217-52.

Certeau, Michel de. The Practice of Everyday Life. Trans. Timothy J. Tomasik. Berkeley: U of California P, 1997.2 vols.

Chatman, Seymour. "Towards a Theory of Narrative." New Literary History 6.2 (1975): 295-318.

Choisy, Auguste. Histoire de l'architecture. Paris: Gauthier-Villars, 1899.

Dogville. Dir. Lars von Trier. København: Zentropa Entertainments, 2003.

Do The Right Thing. Dir. Spike Lee. New York: 40 Acres \& A Mule Filmworks, 1989.

France/tour/détour/deux/enfants. Dir. Jean-Luc Godard and Anne-Marie Miéville. Paris: Institut National de l'Audiovisuel, 1978.

Frye, Brian. "Interview with John Smith." Hidden Currents Special issue Millennium Film Journal 39-40 (2003): <http://mfj-online.org/journalPages/MFJ39/JohnSmith.html>.

Gardies, André. L'Espace au Cinema. Paris: Klincksieck, 1993.

Gestalt Theory of Visual Perception <http://www.users.totalise.co.uk/ kbroom/Lectures/Gestalt.htm>.

Grodal, Torben. Moving Pictures: A New Theory of Film Genres, Feelings, and Cognition. London: Clarendon, 1997.

Helsinki Forever. Dir. Peter Van Bagh. Helsinki: Illume, 2009.

Herman, David, Manfred Jahn, and Marie-Laure Ryan, eds. The Routledge Encyclopedia of Narrative Theory. New York: Routledge, 2005.

Hevern, Vincent. "Introduction and General Overview." Narrative Psychology: Internet and Resource Guide (2004): <http://web.lemoyne.edu/ hevern/narpsych/nrintro.html>.

If Buildings Could Talk. Dir. Wim Wenders. Berlin: Neue Road Movies, 2010.

Keiller, Patrick. "The City of the Future." City: Analysis of Urban Trends, Culture, Theory, Policy, Action 7 (2003): 3.

La Haine. Dir. Mathieu Kassovitz. Paris: Canal+, 1995.

Landau, Idan. "Hierarchical Structure in Schematic Representations: Aspects of Meaning in the Cinematic Shot." Journal of Pragmatics 26 (1996): 737-66.

L'Arroseur arosé. Dir. Lumière Brothers. Lyon: Lumière Frères, 1895.

Lawson, Bryan. Language of Space. London: Architectural P, 2001.

Le Corbusier. Les Oeuvres Complètes. Zürich: Erlenback-Zürich, 1929.

Le Fabuleux destin d'Amélie Poulain. Dir. Jean-Pierre Jeunet. Paris: France 3 Cinéma, Canal+, 2001.

Lefebvre, Henri. The Production of Space. Trans. Donald Nicholson-Smith. Oxford: Wiley-Blackwell, 1991.

Le Samouraï. Dir. Jean-Pierre Melville. Paris: Compagnie Industrielle et Commerciale Cinématographique, 1967.

Molok, Nicolas. "L'Architecture parlante, ou Ledoux vu par les Romantiques." Romantisme 92 (1996): 43-53.

My Girlfriend's Boyfriend. Dir. Eric Rohmer. Paris: Les Films du Losange, 1987.

Penz, François. "Architecture and the Screen from Photography to Synthetic Imaging Capturing and Building Space, Time and Motion." Architectures of Illusions: From Motion Pictures to Navigable Interactive Environments. Ed. Maureen Thomas and François Penz. Bristol: Intellect, 2003. 135-64.

Penz, François. "The Architectural Promenade as Narrative Device: Practice-based Research in Architecture and the Moving Image." Digital Creativity 15.1 (2004): 39-51.

Psycho. Dir. Alfred Hitchcock. Los Angeles: Shamley Productions, 1960.

Perec, Georges. Species of Spaces and Other Pieces. London: Penguin Classics, 1997.

Psarra, Sophia. Architecture and Narrative: The Formation of Space and Cultural Meaning. London: Routledge, 2009.

Raban, Jonathan. Soft City. London: Picador, 1974.

Ryan, Marie-Laure. "On the Theoretical Foundations of Transmedial Narratology." Narratology beyond Literary Criticism. Berlin: Walter de Gruyter, 2005. 1-23.

Smoke. Dir. Wayne Wang. Hollywood: Miramax Films, 1995.

The Girl Chewing Gum. Dir. John Smith. London: Royal College of Art, 1976.

The Lord of the Rings. Dir. Peter Jackson. New York: New Line Cinema, 2001.

The Naked City. Dir. Jules Dassin. Los Angeles: Mark Hellinger Productions, 1948.

Thomas, Maureen. "The Moving Image of the City: Expressive Space/Inhabitation/Narrativity: Intensive Studio Workshop on 'Continuity of Action in Space'." Urban Cinematics: Understanding Urban Phenomena Through the Moving Image. Ed. François Penz and Andong Lu. Bristol: Intellect, 2011. 281-309.

Tschumi, Bernard. Architecture and Disjunction. Cambridge: MIT P, 1996.

Two or Three Things I Know About Her. Jean-Luc Godard. Paris: Argos Films, 1967.

Viollet-le-Duc, Eugene-Emmanuel. Entretiens sur l'architecture. Paris: Q. Morel, 1863.

Wenders, Wim. Cinematic Architectures: Wim Wenders Vs SANAA (2010): $<$ http://irenebrination.typepad.com/irenebrination_notes_on_a/2010/08/cinematic-architectures-wimwenders-vs-sanaa.html>.

West Side Story. Dir. Robert Wise and Jerome Robbins. New York: The Mirisch Corporation, 1960. 
François Penz,

"Towards an Urban Narrative Layers Approach to Decipher the Language of City Films"

page 12 of 12

CLCWeb: Comparative Literature and Culture 14.3 (2012): <http://docs.lib.purdue.edu/clcweb/vol14/iss3/7>

Thematic Issue New Work in Landscape and Its Narration. Ed. Sofie Verraest, Bart Keunen, and Katrien Bollen

Whyte, William H. City: Rediscovering the Center. Philadelphia: U of Pennsylvania P, 2009.

Zazie dans le Métro. Dir. Louis Malle. Paris: Nouvelles Editions de Films, 1960.

Author's profile: François Penz teaches architecture at the University of Cambridge. He co-founded - with Maureen Thomas - the Cambridge University Moving Image Studio (1998-2005) and, more recently, the Digital Studio for Research in Design, Visualization and Communication <http://www.expressivespace.org >. In his research Penz focuses on the narrative organization of space and the expressive use of digital media as an aid to design and communication in architectural and city related issues. In addition to numerous articles, his book publications include the edited volumes Cinema \& Architecture (1997, with Maureen Thomas), Architectures of Illusion (2003, with Maureen Thomas), Screen Cities (2003), and Urban Cinematics (2011, with Andong Lu). E-mail:

<fp12@cam.ac.uk> 